\title{
Exclamatives: A Thematic Guide with Many Questions and Few Answers*
}

\section{Xavier Villalba}

Universitat Autònoma de Barcelona. Centre de Lingüística Teòrica 08193 Cerdanyola del Vallès (Spain)

Xavier.Villalba@uab.cat

\begin{abstract}
In this paper a snapshot is offered of the state of the art in the research on exclamatives, reviewing our current understanding of "classic" issues, like factivity, high degree, or the relationship between exclamatives and interrogatives, and highlighting new theoretical and empirical challenges, such as the contribution of exclamative sentences to a dynamic model of discourse or the placement of exclamative phrases in the left-periphery.
\end{abstract}

Key words: exclamative sentences, factivity, degree, widening.

\section{Table of Contents}

\section{Introduction 4. The form of exclamatives}

2. The meaning of exclamatives 5. Conclusions

3. The use of exclamatives References

\section{Introduction}

The interest in exclamative sentences in modern linguistic theory is customarily traced back to the work by Dale E. Elliott in the early 70's (Elliott 1971, 1974). Elliott designed a pool of tests for determining the exclamative character of English sentences in close contrast with interrogative sentences. Even though of limited application beyond English and burdened with quite heterogeneous a nature, Elliott's approach to the issue in general and his tests in particular have been influential enough to determine the research agenda of the area for nearly two decades. 
On the positive side, the work by Elliott raised attention to exclamative sentences, which, when considered at all, had received a parochial and secondary role with respect to interrogative sentences. It can be said with justice that Elliott set the grounds for a fruitful development of the area in the subsequent years. Consider for instance, his observation that exclamative clauses can only be selected by factive predicates, so that the following contrast arises -note that very makes the sentence necessarily exclamative, another fact pointed out by Elliott:

\section{(1) a. It's amazing how very expensive this wine is.}

b. *I asked how very expensive this wine was.

Even though Elliott just notes this contrast without raising any theoretical consequence, this observation is at the basis of a major debate in the field concerning the proper semantic characterization of exclamative sentences. For instance, Grimshaw (1979) took Elliott's observation a step further and argued that exclamative constructions are factive -that is, they presuppose the truth of the proposition they denote-, so that the illformedness of (1b) results from the clash between the presupposition associated with the exclamative sentence ("This wine was very expensive") and the semantic requirements of the predicate ask, which presupposes ignorance concerning the validity of the proposition denoted by its complement.

This line of research has been formalized in several ways. Gutierrez-Rexach (1996, this volume) derives factivity from the denotation of an illocutionary exclamative operator, which includes a null emotive predicate. A different technical solution -even though with an equivalent import- is pursued in Zanuttini and Portner (2003), where it is argued that the factivity of exclamatives is syntactically encoded by means of a factive operator in CP.

Yet, a different line of research exists that questions the factivity analysis of exclamatives (see Castroviejo 2006 and Mayol this volume). We will consider this issue in more detail in 2.3, but we hope that this brief discussion suffices to make apparent the long-lasting influence of Elliott's pioneering work in the research on exclamative sentences.

Important as it has been, one must acknowledge that Elliott's influence hasn't been always positive, for two reasons. First of all, some tests are of a very limited coverage. For instance, he remarks that subject-verb inversion is a clear test to separate matrix interrogative sentences, which involve inversion, from exclamative ones, which don't:

(2) a. How many books you read!

b. How many books did you read?

Yet, although this test works fine in English or French, it does less clearly in German or Italian, fails altogether in Catalan or Spanish, or is simply unavailable in SOV languages like Japanese. This limited coverage reaches its peak with the 
very test -i.e. English $w h$-exclamatives may be appended with the modifier very: How (very) tall Mary is! -, which is a highly idiosyncratic feature of English exclamatives. Obviously, it would be unfair to charge Elliott for these shortcomings, for he designed the tests for English exclamatives. The responsibility for devising new and more far-reaching tests is to be put on the burden of the community of researchers, and a quick glance at the recent literature shows how difficult this task can be.

Secondly, even though some tests allow for a wider application, and can be arguably taken to reveal some general property of exclamatives, Elliott failed to make clear the exact import of his tests, particularly whether the presumed feature underlying them is syntactic, semantic or pragmatic -which, to be fair with his contribution, is a matter of investigation nowadays. Take for instance, the coordination test, which shows that interrogatives are typically associated with a disjunctive reading in terms of alternatives, whereas exclamatives associate with an additive reading:

(3) a. How expensive is this book? Ten euros \{or rather/\#and even\} twenty in some bookstores?

b. How expensive this book is! Ten euros \{\#or rather/and even\} twenty in some bookstores.

Intuitively, the disjunctive option seems fine with typical interrogative sentences, for it nicely correlates with the exclusive nature of the process of assigning a value to the variable introduced by the interrogative wh-element. Exclamative sentences, instead, do not seem to involve this process, for reasons to be explained -a particularly cogent problem for the proponents of a semantic analysis of exclamatives based on that of interrogatives; see Abels (2004), d'Avis (2002), and Gutiérrez-Rexach (1996, 2001, this volume). However, what is still a matter of debate is the exact signification of this test.

In this paper we will offer a snapshot of the state of the art in the research on exclamatives, reviewing where we are with respect to "classic" issues, like factivity, high degree, or the relationship between exclamatives and interrogatives, and highlighting new theoretical and empirical challenges, such as the contribution of exclamative sentences to a dynamic model of discourse, the placement of exclamative phrases in the left-periphery, and the relation between exclamatives and subject-verb inversion. It goes without saying that the list of discussed issues is not exhaustive, but we believe that it is representative enough to give an accurate picture of the lively research area of exclamatives.

The organization of the article is a classical tripartite division between meaning (section 2), use (section 3) and form (section 4).

\section{The meaning of exclamatives}

In this section we will be concerned with the main aspects involved in the meaning of exclamatives, and the (divergent) solutions devised to account for them. From the 
literature, one can set the following interpretive issues, that we consider in detail in the following subsections:

— high/extreme degree (2.1)

- emotional content (2.2)

- factivity (2.3)

- semantic type (2.4)

\subsection{High degree}

It is a well-attested fact that exclamatives involve somehow the placement of an individual on a scale, and particularly on the extreme of such a scale, as the following example and the paraphrases try to show:

(4) How expensive this wine is!

"This wine is extremely expensive"/"This wine is expensive to an extreme degree"

The immediate question that arises concerns the proper treatment of this interpretive feature, and the answers are, as usually, divergent.

One solution is to derive this meaning from the presence of a maximality operator over degrees, following Rullmann (1995). This is the path that takes GutiérrezRexach (1999) for Spanish degree neuter constructions:

a. ¡Lo

$$
\text { caro }
$$

que es el vino! the.NEUTER expensive that is the wine 'How expensive the wine is!'

b. lo caro $\equiv \operatorname{MAX}\left(\lambda d \lambda\right.$ x.expensive $\left.{ }^{\prime}(d)(x)\right)$

Villalba (2004) extends this analysis to degree $w h$-exclamatives in order to account for the quantificational restrictions that affect exclamatives, namely the very restricted distribution of negation and the necessity of quantifiers over individuals to be specific (see González this volume for a different look at negative exclamatives).

Yet, treating the high/extreme degree meaning as a semantic presupposition following from the maximality operator does not seem an adequate solution. For one reason, there is evidence that this interpretation is not always present in exclamatives, as argued for by Castroviejo (2006), and Gutiérrez-Rexach (1996, this volume). One nice argument comes from degree exclamatives associated with adjectives denoting a closed scale, like full or $d r y$ (Castroviejo 2006). Crucially,

(6) How dry the towel is!

does not entail that the towel is dry (cf. wet: How wet the towel is! $\Rightarrow$ "The towel is wet"), which makes the extreme degree interpretation ("The towel is dry to an 
extreme degree") nonsensical, particularly if one considers that the assertive version without a modifier (The towel is dry) denotes a higher degree of dryness -indeed the highest- than the exclamative version. ${ }^{1}$ As we will see in 2.2, these examples call for a treatment involving a speaker-based standard of comparison: "The towel is drier than I expected".

Given the difficulties of a presuppositional analysis, the most popular solution takes this high/extreme degree to be an implicature, hence pragmatic in nature. For example, Zanuttini and Portner (2003) derive it from the semantic operation of widening. They argue that, in exclamative sentences, the individual is placed in the extended interval built over the previous standard scale. The mechanism of widening is formally defined as follows:

\section{(7) Widening:}

For any clause $\mathrm{S}$ containing $\mathrm{R}_{\text {widening }}$, widen the initial domain of quantification for $\mathrm{R}_{\text {widening }}$, $\mathrm{D} 1$, to a new domain, $\mathrm{D} 2$, such that

(i) $[[S]]_{w, D 2,<}-[[S]]_{w, D 1,<} \neq \varnothing$ and;

(ii) $\forall x \forall y[(x \in D 1 \& \mathrm{y} \in(D 2-D 1)) \rightarrow x<y]$.

They illustrate the point with the following scenario, which merits a full cite:

As for the contribution of widening, we assume that $\mathrm{R}_{\text {widening }}$ has the semantics of a quantificational operator. To see the role of this operator, let us consider the following context. We're discussing which hot peppers some of our friends like to eat. The domain of quantification for $\mathrm{R}_{\text {widening }}$, let us call it $\mathrm{D} 1$, is a set of peppers which contains (in increasing order of spiciness): poblano, serrano, jalapeño, and güero. Our friends who like spicy food tend to eat the poblanos, serranos, and occasionally jalapeños. About one of them, we say (29) [=The things he eats! XV]. In this context, the sentence implicates that he eats all types of peppers, not only all those in D1 but also, for example, the habanero, which is so spicy that it often makes people ill. Uttering (29) thus causes the domain of $\mathrm{R}_{\text {widening }}$, $\mathrm{D} 1$, to be expanded to D2, including this additional type. This expansion of the domain is the widening component of meaning of exclamatives. Zanuttini and Portner (2003)

Note that the condition (ii) in (7) states that any element of the widened domain not present in the initial domain must occupy a higher position in the scale than any element of the initial domain, i.e. we must append the scale by its extreme. This condition forces, according to Zanuttini and Portner, the generation of a conventional implicature of high/extreme degree. To support their analysis, they point out that the implicature cannot be conversational, for it is neither cancelable nor detachable (see Grice 1989), and offer the following examples:

1. Moreover, as pointed out by Castroviejo (2006), these examples question the factivity analysis of exclamatives; see 2.3 below. 
(8) a. \#How very cute he is! -though he's not extremely cute.

b. He's quite cute! -though not extremely cute.

In (8a) we see that the high/extreme degree implicature cannot be canceled, and $(8 \mathrm{~b})$ is intended to show that the implicature is attached to the exclamative form, not to the meaning of the sentence. However, this characterization is controversial. On the one hand, as pointed out by Castroviejo (2006), continuations that do not cancel the implicature yield bad results as well (her exs. (79) and (81)):

(9) a. \#How very cute he is! -but he lives a thousand miles away.

b. \#How very cute he is! -because his mother is also extremely cute.

Note that the last example even explicitly reasserts the high-degree implicature, which leads her to conclude that the problem has to do with the combination of two different speech acts, an exclamation and an assertion. This line of research might explain why embedded exclamatives (which lack illocutionary force) are fine in these contexts:

(10) I'm amazed at how very cute he is, though I know he's not extremely cute.

On the other hand, it is far from being settled that the implicature is nondetachable. Villalba (2003) considers the case of Spanish hidden exclamatives (see Masullo 1999), like the following:

(11) a.

¡Marta es de buena!
Marta is of good
'Marta is so good!'

b. ¡El chico es de travieso! the boy is of naughty 'The boy is so naughty!'

Crucially, if we apply the standard defeasability test, one is forced to conclude that this construction does carry the scalar implicature associated with overt exclamatives, which, consequently, is not attached to the exclamative form:

(12) a. ¡Marta es de buena! \#Si es que lo es. Marta is of good if is that it is 'Marta is so good! \#If at all.'

b. ¡El chico es de travieso! \#Aunque no demasiado. the boy is of naughty although not too.much 'The boy is so naughty! \#Although not much.'

Hence, the conventional implicature defended in Zanuttini and Portner (2003) seems highly problematic, and must be rethought on different grounds. 
A different line of research would be treating the implicature as conversational, which would explain its strong context-dependency. Yet, as originally pointed out by Paul Portner (p.c.), the conversational characterization is problematic, for the implicature at issue can hardly be computable from the interaction of Grice's Cooperative Principle with any conversational maxim, unlike typical scalar conversational implicatures, which arise from apparent violations of the Maxim of Quantity. Consider a typical case:

(13) a. Some students passed the exam.

b. Not all the students passed the exam.

(13)a yields the scalar implicature in (13)b through the following reasoning. Unless some evidence points to the contrary, we consider (13)a to be the most informative utterance the speaker is able to make. Since a more informative alternative ("All the students passed the exam") is not chosen, we take for granted that it doesn't hold, and we implicate its negation ("Not all the students passed the exam").

We are thus in a quandary, for it seems that this high/extreme degree meaning hardly fits in with the standard Gricean typology of implicated meanings. It comes without surprise, then, that current efforts are pointed toward a more stable meaning of exclamatives: its emotive import.

\subsection{Emotive content}

We have just seen that the high/extreme degree usually associated with exclamatives cannot safely characterize exclamatives from a semantic point of view. One piece of evidence that another meaning feature is involved is the following contrast:

(14) a. How expensive this wine is! \# which doesn't surprise me at all, because it's kosher.

b. This wine is extremely expensive, which doesn't surprise me at all, because it's kosher.

While the exclamative sentence necessarily involves a meaning of unexpectedness -hence the infelicity of the continuation-, an assertion containing an elative doesn't. The basic intuition is that a comparison is involved between the real degree -the wine's price- and the speaker's expectation of what a standard degree should be -her expectation about the normal price of a wine in a particular context. Let us develop the example to make the things clearer. Take for instance, a situation in which my budget for a romantic dinner with my wife is 150 euros. Then when I have a look at the wine menu, an Australian Pinot Noir catches my eye, and I realize that it's priced 200 euros. In such a situation, $m y$ scale of expensiveness, as applied to wines, becomes dramatically extended far beyond my expectations, allowing me to exclaim: How expensive this wine is! Yet, the very same 
utterance can be appropriate in a situation when a poor beggar is confronted with a 3 euros bill for an infamous tetra-brik wine. What remains stable is the fact that the price is beyond our expectations, while the exact price changes contextually. This gives us the following paraphrase:

(15) How expensive this wine is! $\Rightarrow$ "This wine is more expensive than I expected"

This implicit comparison between two degrees can be traced back to the intuitions in Milner (1978), and has been developed in different ways by d'Avis (2002), Gutiérrez-Rexach (1996, this volume), and Zanuttini and Portner (2003). We will concentrate on two very different proposals: Zanuttini and Portner (2003), who analyze the emotive component as an implicature derived from the semantic operation of widening, and Gutiérrez-Rexach (1996, this volume), who does it from an illocutionary operator.

Zanuttini and Portner (2003) argue that, in exclamative sentences, a set of propositions is construed of the form ' $\mathrm{x}$ has the property $\mathrm{P}$ to a degree $\mathrm{d}_{1}$ ', ' $\mathrm{x}$ has the property $P$ to a degree $d_{2}$ ', ... ' $x$ has the property $P$ to a degree $d_{n}$ ', and the actual proposition is build on a degree $\mathrm{d}_{\mathrm{n}+\mathrm{i}}$, belonging to the extended interval built over the previous standard scale. One immediate advantage of the widening approach, Zanuttini and Portner argue, is the possibility of deriving the wide range of meanings usually associated with exclamative sentences. Take, for instance, the surprise flavor we tend to perceive in exclamatives. Since widening extends the domain of quantification to include values not contemplated in the speaker's initial expectations, a meaning of surprise follows straightforwardly from general conversation strategies. If we come back to the romantic dinner scenario, the uttering of How expensive this wine is! indicates that I am extending the original set of propositions ordered according to the degree of expensiveness of the wine to include a new proposition containing the expensive Australian Pinot Noir. As a consequence, the new domain widens the initial set to include the unexpected, which generally results in an emotive meaning of surprise or unexpectedness (or annoyance). Gutiérrez-Rexach (1996, this volume) takes a different direction and resorts to an illocutionary operator over propositions that includes a null emotive predicate as part of its denotation. ${ }^{2}$ Let us consider his proposal in some detail.

The point of departure is the emotive attitude we have in exclamatives toward a certain fact. Hence, in a exclamative like

(16) How tall John is!

expresses an emotive attitude toward the fact that John is tall to a certain degree. Accordingly, Gutiérrez-Rexach proposes an illocutionary operator that takes as arguments a speaker, a situation, and a proposition:

2. This technical solution maintains the benefits of the classical "performative verb hypothesis" (see Lewis 1970, Ross 1971, Sadock 1970), without its theoretical shortcomings. 
(17) Let $a$ be the speaker, $w$ a world (typically the actual world), $p$ a proposition, and $\mathrm{P} \in \mathrm{EMOT}$ (the set of emotive properties). Then, EXC $=_{\mathrm{def}} \lambda a_{i} \cdot \lambda w_{s} \cdot \lambda p_{<s, t>}$ $\exists P_{<s,<<s, t>,<e, t>>>}[\mathrm{P}(\mathrm{w})(\mathrm{p})(\mathrm{a})]$.

Consider how we apply this definition to (16):

(18) $\operatorname{EXC}(a)(w)\left(\lambda w^{\prime}\left[\lambda d[\operatorname{tall}(w)(j, d)]=\left[\lambda d\left[\operatorname{tall}\left(w^{\prime}\right)(j, d)\right]\right]\right)\right.$ iff

$\exists P \in \operatorname{EMOT}\left[P(w)\left(\lambda w^{\prime}\left[\lambda d[\operatorname{tall}(w)(j, d)]=\left[\lambda d\left[\operatorname{tall}\left(w^{\prime}\right)(j, d)\right]\right]\right)(a)\right.\right.$

This formula tells us that in the current situation the speaker has an emotive attitude toward the fact that John is tall to a certain degree $d$. Now we are able to express the somewhat slippery emotional content associated with exclamatives as a presupposition deriving from the denotation of the exclamative operator. However, as Gutiérrez-Rexach acknowledges (Gutiérrez-Rexach 1996):

There is something else to the semantics of (44)[= our (18), XV] that is not present in the above translation, namely that the degree of John's tallness is greater than any other degree in a scale of degrees of tallness. This scale is determined by the speaker's expectations. There would be no reason to utter (44) in a situation in which the speaker discovers that John is as tall as he expected or less tall than he expected. This is the reason why the adjective tall may be modified by adjectives like very or extremely but not by adjectives like reasonably.

In order to solve this problem he resorts to an ordering relation between degrees grounded on the speaker's expectations, even though he is not explicit enough concerning the placement of this relation into the picture.

\subsection{Factivity}

As mentioned in section 1, Elliott $(1971,1974)$ observed that exclamative clauses can only be selected by factive predicates, so that the following contrast arises -note that very makes the sentence necessarily exclamative:

(19) a. It's amazing how very expensive this wine is.

b. *I asked how very expensive this wine was.

Even though Elliott just notes this contrast without raising any theoretical consequence, Grimshaw (1979) went a step further and argued that exclamative constructions are factive, so that the ill-formedness of (19b) results from the clash between an exclamative construction, which presupposes the truth of the proposition it denotes, and the predicate $a s k$, which presupposes ignorance concerning the validity of the proposition denoted by its complement. A connected observation by Grimshaw (1979) is the fact that exclamatives cannot serve as answers to questions (her ex. 150; the \# mark is added): 
(20) Q: How tall is John?

A: \#How tall John is!

Her explanation resorts to a general conversational rule that forbids using as a response to a question an utterance that presupposes the answer to that question, which is at stake in the following dialogue as well (the \# mark is added):

(21) Q: Did Bill leave?

A: \#It's odd that he did.

A': \#I'd forgotten that he did.

This is intended to show that factivity is a major semantic property of exclamatives, and it is one of the basic arguments presented by Zanuttini and Portner (2003) to justify the presence of a factivity operator in exclamative sentences. A different account of the factivity nature of exclamatives is defended in GutierrezRexach (1996, this volume), where the responsible factor is a null emotive predicate that forms part of the meaning of the exclamatory operator EXC.

Yet, a different line of research exists that considers the things differently. Castroviejo (2006) and Mayol (this volume) criticize the factivity analysis of exclamatives on different grounds. One outstanding empirical fact that can hardly be explained under the factivity approach is the presence of negation. If the propositional content of the exclamative is presupposed, Portner and Zanuttini (2000) argue, no difference in terms of truth-conditions should follow from adding negation, just as happens with factive predicates:

(22) a. I regret having bought this book. $\Rightarrow$ I have bought this book.

b. I don't regret having bought this book. $\Rightarrow$ I have bought this book.

Note that this amounts to saying that whenever negation is embedded in a exclamative sentence, it must be expletive, which is true to a wide extent, but cannot be totally correct under the light of the empirical data discussed in Villalba (2004) and González (this volume). Even though generally negation is expletive within exclamatives (see Espinal 1997 and Portner and Zanuttini 2005), negative quantitative exclamatives are possible as well:

(23) a. ¡Cuántos libros no pudiste leer jamás! how.many books not could.you read never 'How many books you could never read!'

b. ¡Caramba, la de cosas que no compró nadie! why the.FEM of things that not bought nobody 'Why, the things that nobody bought!' 
As the licensing of the negative polarity items jamás ('never') and nadie ('nobody') shows, we are dealing here with standard negation. Under the assumption that exclamative sentences are inherently factive, the negative import of negation in these examples remains unexplained.

\subsection{Semantic type}

The late sixties assisted to the raise of a long-awaited revolution in the linguistic field: the building of a rigorous and ambitious semantic theory (two excellent brief backgrounding works are Portner and Partee 2002 and Partee 2004). Richard Montague, and David Lewis as leading figures built on the truth-based logic tradition traced back to Gottlob Frege and developed in the postwar period by Rudolf Carnap and Alfred Tarsky to set the grounds for formal semantics, particularly one based on the following two key features - usually formalized with the tools of intensional logic and a model structure based on possible worlds:

— the meaning of sentences is based on their truth-conditions;

- syntax and semantics build up compositionally and hand-in-hand.

These two core ideas allowed fruitful semantic research. On the one hand, truth conditions were a testable basis for semantics, which had been almost excluded from linguistic research either explicitly as a fuzzy and unsuitable matter of study (cf. Leonard Bloomfield ideas on the subject), or implicitly as a mere interpretive appendix to syntax (the standard generative tradition). On the other hand, the assumption of compositionality and a direct syntax-semantics correspondence opened the way to more explicit and simpler analyses, that questioned the core of Katz-Postal Hypothesis (Katz and Postal 1964) and consequently the very necessity of multistratal models -i.e. of transformational grammar. $^{3}$

Immediately after the first works by Montague and his followers, the issue was raised concerning those sentence types which are not intuitively analyzable in terms of truth conditions. In other words, we have a straightforward way of evaluating whether the proposition denoted by the sentence Mary is intelligent is true or false: roughly, it will be true (in a given world) if Mary is intelligent (in such a world). Yet, we don't have an intuitive way to perform the same evaluation with the proposition denoted by Is Mary intelligent?: under which conditions can we evaluate whether it is true or false? To cope with this theoretical problem, several semantic answers have been suggested, with a different attachment to the original Montagovian framework (see, for instance Asher and Lascarides 1998, Bennett 1977, Bittner 1998, Ginzburg 1995a, 1995b, Ginzburg and Sag 2001, Groenendijk and Stokhof 1982, 1989, Higginbotham 1991, Zimmerman 1985). The most influential -and orthodox- is the one developed by Hamblin (1973) and Karttunen (1977), who build the denotation of questions on the set of answers: the set of true

3. It comes without surprise that these two main postulates of formal semantics have been much combated by Chomsky (see, for instance, Chomsky 1975). 
answers in Hamblin's analysis, and the set of possible answers in Karttunen's analysis. ${ }^{4}$ In either case, interrogatives denote sets of propositions $(<<s, t>, t>)$. Let us consider one example from Karttunen (1977):

(24) a. ...what John reads.

b. ...what-John-reads' $\equiv \hat{\mathrm{p}} \vee x\left[{ }^{\vee} \mathrm{p} \wedge \mathrm{p}={ }^{\wedge} \operatorname{read}_{*}{ }^{\prime}\left(\mathrm{j},{ }^{\vee} \mathrm{x}\right)\right.$

As Karttunen himself comments, the translation in (24b)

denotes a set which contains, for each thing that John reads, the proposition that he reads it. If John happens to read only the New York Times and Playboy, then the indirect question what John reads denotes a set containing only the two propositions expressed by "John reads the New York Times" and "John reads Playboy". Karttunen (1977)

This line of analysis proved elegant and quite successful, so that it comes without surprise that the first formal treatments of the semantics of exclamatives mirrored it, particularly if one considered the fact that exclamatives where typically built on $w h$-elements that mostly were used for exclamatives and interrogatives interchangeably. Hence, Gutiérrez-Rexach (1996) argues that "interrogatives and exclamatives have basically the same denotation" (a similar position is assumed in Abels 2004, d'Avis 2002, Sæbø 2005, and Zanuttini and Portner 2003, with minor differences). The difference has to do with the presence of an illocutionary exclamative operator that takes as arguments a speaker $a$, a situation $w$, and a proposition $p$ :

\section{$\operatorname{EXC}(a)(w)(p)$}

For instance, consider the denotations assigned to the degree interrogative and the exclamative in (26) and (27), respectively:

(26) How tall John is? $\equiv \lambda w^{\prime}\left[\lambda d[\operatorname{tall}(w)(j, d)]=\left[\lambda d\left[\operatorname{tall}\left(w^{\prime}\right)(j, d)\right]\right.\right.$

(27) How tall John is! $\equiv \operatorname{EXC}(a)(w)\left(\lambda w^{\prime}\left[\lambda d[\operatorname{tall}(w)(j, d)]=\left[\lambda d\left[\operatorname{tall}\left(w^{\prime}\right)(j, d)\right]\right)\right.\right.$

The exclamative denotation is built on that of interrogatives plus the exclamative operator, which introduces a speaker and an actual world.

This approach, however, is not devoid of problems. In section 1, we have mentioned the coordination test devised by Elliott (Elliott 1971, 1974) to distinguish exclamatives from interrogatives:

4. Another major difference between Hamblin's treatment and Karttunen's concerns the primary data the analysis is assumed to account for. Whereas Hamblin (1973) concentrates on direct questions, and pays no attention to indirect questions, Karttunen (1977) only considers the latter, and for direct ones he assumes the performative approach suggested by Lewis (1970). According to this view, direct questions are true whenever they are uttered. 
(28) a. How expensive is this book? Ten euros \{or rather/\#and even \} twenty in some bookstores?

b. How expensive this book is! Ten euros \{\#or rather/and even\} twenty in some bookstores.

Crucially, the disjunctive option was typically associated with interrogatives, for this is compatible with the introduction of variable. Yet, this line of reasoning doesn't follow from the unified analysis.

A bigger problem, however, seems to come from the empirical evidence suggesting that indeed exclamatives and interrogatives denote different semantic objects. This line of research is defended in Ginzburg and Sag (2001) and Castroviejo (2006), who argue that declaratives, interrogatives and exclamatives may be selected by a specialized set of predicates because they denote different entities:

(29) declaratives $\rightarrow$ propositions

a. I believed that John was a fool.

b. \#I believed whether John was a fool.

c. \#I believed what a fool John was.

(30) interrogatives $\rightarrow$ questions

a. \#I asked that John was a fool.

b. I asked whether John was a fool.

c. \#I asked what a fool John was.

(31) exclamatives $\rightarrow$ facts

a. \#I was struck by that John was a fool.

b. \#I was struck by whether John was a fool.

c. I was struck by what a fool John was.

To reinforce their point, they introduce a test: declaratives can be used equatively with nominals denoting propositions, interrogatives, with nominals denoting questions, and exclamatives with nominals denoting facts. Hence, the following contrast follows (Ginzburg and Sag 2001): ${ }^{5}$

5. This is a problem for Sæbø (2005) who argues that exclamatives denote true sentences of type $<\mathrm{s}, \mathrm{t}>$, namely propositions. 
(32) a. The amazing fact I noticed during my visit was how modest all Ruritarians are.

b. \#An interesting claim Mo has put forward is what a reputation Bo has carved for herself among computational ethologists.

c. \#An intriguing question I've been investigating is what a reputation Bo has carved for herself among computational ethologists.

As a matter of fact, when the proper nominal-sentence type correspondence is chosen, grammaticality arises:

(33) a. The amazing fact I noticed during my visit was how modest all Ruritarians are.

b. An interesting claim Mo has put forward is that Bo has carved a reputation for herself among computational ethologists.

c. An intriguing question I've been investigating is which reputation Bo has carved for herself among computational ethologists.

This kind of evidence leads Ginzburg and Sag (2001) and Castroviejo (2006) to propose that exclamatives denote facts, with interesting consequences on the contribution of exclamatives to the Common Ground (see Castroviejo 2006, this volume).

\section{The use of exclamatives}

One major contribution of analytic philosophy has been the consideration of language as a human activity which is certainly outstanding and unique, but nonetheless amenable to analysis in terms of rational action. There is consensus on the major role and long-lasting influence that the ground-breaking contribution of $\mathrm{J}$. L. Austin in his William James Lectures (published posthumously as Austin 1962) has had in modern pragmatic theory. Austin is deservingly famous for having introduced the threefold distinction in the description of an utterance between locutionary, illocutionary and perlocutionary acts. Simplifying, we can say that a locutionary act consists in uttering a series of words with a certain meaning, an illocutionary act consists in uttering a series of words with a certain force -the illocutionary force of the utterance-, and a perlocutionary act consists in uttering a series of words which will produce a certain effect in the hearer. To take Austin's classical example, when I utter

\section{(34) Shoot her.}

I am performing a locutionary act, that of expressing the meaningful words shoot and her; I am performing an illocutionary act, which can be an order, an advice, or a request -we say then that the utterance has the illocutionary force of 
an order, an advice, or a request, respectively-; and finally, if I am convincing enough to persuade the hearer to shoot her, I am performing a perlocutionary act of persuasion. Austin's recognition of more layers of meaning than just the literal meaning associated with words is a milestone in the philosophy of language and in linguistics, and influenced decisively John R. Searle's Speech Act Theory -Searle was Austin's student at Oxford (see Martinich 2001 and Searle 2001).

\subsection{Exclamatives as expressive speech acts}

According to Searle, to understand language one must understand the speaker's intention. Hence, the meaning of a sentence cannot be separated from its use, and consequently no useful distinction exits between locutionary and illocutionary acts. Hence, even though he admits speech acts must carry a propositional content, he takes the meaning of a sentence to be the illocutionary force of the utterance containing it. Thus, in Searle's (Searle 1969) analysis, the sentences:

(35) a. Sam smokes habitually.

b. Does Sam smoke habitually?

c. Sam, smoke habitually!

d. Would that Sam smoked habitually!

have the same propositional content (we predicate of Sam that he smokes) but differ in the illocutionary force (a statement, a question, a command and an expression of desire, respectively).

In order to tease apart the different speech acts, Searle $(1969,1979)$ analyzes the set of conditions or rules involved in the production of a felicitous speech act. In a nutshell, he considers four basic sets of conditions:

- propositional content conditions

- preparatory conditions

- sincerity condition

- essential condition

The propositional content conditions restrict the form of the proposition accompanying the speech act. In the classical example of a promise, it is required that the proposition involve a predication of a future act of the speaker. The preparatory conditions include that the realization of the future act of the speaker be preferable to its nonrealization. The sincerity rule requires that the speaker making a promise had the intention to perform the promised act. Finally, the essential condition of a promise consists in putting the speaker in the obligation to do the promised act by uttering a conventional sentence.

When we consider exclamative sentences against this background, difficulties arise at different levels (see Castroviejo this volume, who expresses skepticism 
concerning a proper treatment in terms of Searle's Speech Act Theory). Yet, we may sketch the following analysis, at least for prototypical instances. First of all, the propositional content condition should include the basic features we expect for most exclamatives:

(35) propositional content conditions:

a. speaker expresses the proposition that $p$ in the utterance of $\mathrm{T}$; and

b. expressing that $p$, the speaker predicates an emotional attitude towards a certain state of affairs or degree.

Regarding the preparatory conditions, since the hearer is not taken into account, one can conclude that there are none. As for the sincerity condition, it is clear that the speaker is committed to the truth of the proposition involved and of the emotional attitude expressed. Note that when the sincerity condition is violated, we obtain a rhetorical exclamative (see Castroviejo 2006):

(36) A: Surt d'aquí o trucaré a la policia!

'Get out of here or I call the police!'

B: Ai sí, quina por que em fas!

'Oh boy, how you scare me!'

Finally, we can consider that the essential condition for a exclamative speech act to hold is the following:

\section{(37) essential condition:}

a certain state of affairs or degree exists depassing the speaker expectations which causes the speaker an emotional reaction.

Obviously, this is far from being a fully-fledged analysis of the exclamative subtype of expressive speech act, and it is even dubious that Searle's system, as it stands, can account for exclamatives appropriately; however, Speech Act Theory has proven a fruitful framework for analyzing a wide range of semantic and pragmatic phenomena, so we can expect that new insights may follow from considering exclamatives under its light. Whether this expectation is fulfilled future research will tell.

\subsection{Exclamatives and the common ground}

The most influential model of discourse interaction is the one developed by Robert C. Stalnaker (Stalnaker 1978, 1988, 1998, all three works collected in Stalnaker 1999; see also Gunlogson 2001 for refinements, and Atlas 2005, and Gauker 2003 for contrasting views). Taking as a point of departure the Gricean insight that speech is a rational activity governed by general rules intended to ensure cooperation between the participants, Stalnaker remarks the twofold nature of context. On the 
one hand, the context of communication is modified as we speak by the content of our utterances. On the other hand, the context determines the way the content of our utterances is interpreted. Hence, the speaker's contribution doesn't create the communication space, but rather adds to a preexistent shared information against which it must be interpreted. This bulk of knowledge the speaker assumes to be shared with the hearer, Stalnaker calls Common Ground, and he represents it by means of a set of propositions -which are in turn (controversionally) defined as sets of possible worlds, the context set. Let us quote a perspicuous passage from Stalnaker 1998 (the pages correspond to the reprinted version in Stalnaker 1999):

We can represent the information that defines the context in which a speech act takes place with a set of possible situations or possible worlds -the situations that are compatible with the information. This set, which I have called the context set (Stalnaker 1974)[,] will include all the situations among which the speakers intend to distinguish with their speech acts. The presented common information -what is presupposed in the contextis what all these worlds have in common. An assertion can then be understood as a proposal to alter the context by adding the information that is the content of the assertion to the body of information that defines the context, or equivalently, by eliminating from the context set -the set of possible worlds available to speakers to distinguish betweenthose possible worlds in which the proposition expressed in the assertion is false.

Once we have determined the structure of the Common Ground, we must bear in mind that the way an assertion alters the context is twofold. We have seen that the content of the asserted proposition alters the context adding information, but since we are performing a speech act, the very same action of asserting alters the context too, and it does it before the content of the assertion does. This finer-grained analysis of the context change potential of speech acts doesn't make much difference when assertions are considered, but it might be important for a proper treatment of other speech acts. Indeed, Castroviejo (this volume) argues that exclamative sentences do modify the Common Ground, but in a very different way than declarative sentences. She considers three levels:

\section{- the descriptive content}

- the expressive content

- the speech act itself

In the case of a exclamative like How tall Mary is!, the descriptive content would correspond to the proposition roughly denoting that "Mary is tall beyond my expectations". The expressive content would correspond to the speaker's emotive attitude toward this state of affairs. Both the descriptive and the expressive content are typically implied, that is they are not asserted, but taken for granted by the speaker -i.e. its is treated as noncontroversional; see Atlas (2005) for the concept. Note that according to Castroviejo, neither the descriptive, nor the expressive content can modify the Common Ground for they are nonasserted information. She offers the following dialogues to support her claim, which are inspired on tests by Ginzburg and Sag (2001): 
(38) a. I've got some news / you're going to love this / check this out: Pau is very tall.

b. I've got some news / you're going to love this / check this out: \#How tall Pau is!

(39) A: How do you feel about Pau's high degree of tallness?

B: \#How tall he is!

The contrast in (38) shows that the descriptive content of the exclamative cannot be used as new information to be added to the Common Ground, for even though we are conveying the content that "Paul is very tall" this is implied rather than asserted. A similar situation concurs in the case of the expressive content. As (39) shows, the expression of the emotive attitude of the speaker doesn't count as a proper informative contribution to the Common Ground ${ }^{6}$ Hence, the only element available to contribute to the Common Ground seems to be the very same speech act. As Castroviejo (this volume) puts it:

From the moment that a speaker utters an exclamative, the rest of the participants infer that s/he is emotional because of somebody's high degree of adj-ness, this becomes part of the Common Ground and influences the conversation. The same happens if, instead of uttering an exclamative, the participant smiles at somebody's comment. The rest of the participants use this information and interpret it, but the participant who has smiled has not performed this action in order to convey to the participants that the previous comment makes him/her smile (provided that we are dealing with an honest smile), but s/he just felt like smiling as a response to a stimulus. Another consequence of this behavior is also analogous to the case of exclamatives: a smile cannot be used to answer a question. Of course, if somebody asks Are you okay?, we can infer from a smile that the person is fine, but the smile does not qualify as a proper answer, because the information is not verbally codified as an assertion. What differentiates a nonlinguistic action such as a smile from an exclamative is that the latter includes the cause of the emotional attitude, which corresponds to what I have treated as the (backgrounded) descriptive content.

One must note that her view strongly relies on the much vague Stalnakerian distinction between the two ways the context is altered by a speech act, and should be tested on wider grounds, beyond exclamatives, to make sure we are not dealing with an ad hoc device. Yet, the range of constructions analyzed by Castroviejo (this volume) suggests that this line of research may prove fruitful.

\section{The form of exclamatives}

A postview on the history of Generative Grammar shows us the crucial role wh-interrogatives have played in the development of the framework. From the very begin-

6. The exact nature of the implicated content is a matter of hot debate. For Potts $(2005,2007)$, it would be a conventional implicature, whereas for Schlenker (2007), it should be considered a presupposition. 
ning, interrogatives built most arguments supporting transformational analyses to English grammar (see Chomsky 1955, 1957, 1965). However, $w h$-interrogatives have been a motor of change of the theory, as well. It is not mere coincidence that the shift the generative framework initiated in the early seventies, and that gave rise to the Principles and Parameters model in the eighties was partially inspired by the study of the restrictions on $w h$-fronting (see Chomsky 1973 and Ross 1967). Furthermore, the shape and content of the Principles and Parameters model sketched in Chomsky (1981) was heavily redrawn on the bases of crosslinguistic evidence involving $w h$-interrogatives. Hence James Huang's thesis (Huang 1982) on wh-constructions in Chinese became a classical reference for any study on the levels of representation in grammar, and on parameter setting across languages. At the same period, wh-movement served as a test for the initial attemps to formulate the PRO-drop (or null subject) parameter (see Rizzi 1982), and crosslinguistic comparison introduced the issue of multiple $w h$-fronting, which has been a matter of continuous research (see Lasnik and Saito 1992, Pesetsky 2000, Richards 1997, and Rudin 1988).

We are using the term wh-movement, but to be fair, the effort was almost completely placed on interrogative $w h$-elements. For instance, in Cheng and Corver (2006), a reference book on $w h$-movement, the presence of $w h$-exclamatives is almost nonexistent. What do exclamatives add to the received view on $w h$-movement? In the following sketchy paragraphs we will point out some more or less well stated facts concerning the syntax of exclamative sentences, and many more unsolved questions.

\subsection{Moving Why?}

Within the generative tradition, two basic mechanisms have served to formalize the properties of $w h$ - (and verb) movement: abstract agreement in a Specifier-Head configuration and feature checking. The former tool was pervasive in the early developments of the Principles and Parameter model, and still has a currency under a series of criteria, the most conspicuous one being the wh-Criterion (Rizzi 1996) -other criteria present in the literature include the Negation Criterion (Haegeman and Zanuttini 1996) or the Focus Criterion (Brody 1990):

(40) The $w h$-Criterion

A. A wh-operator must be in a Spec-Head configuration with an $\mathrm{X}_{[+w h]}^{\mathrm{o}}$.

B. An $\mathrm{X}_{[+w h]}^{\mathrm{o}}$ must be in a Spec-Head configuration with a wh-operator.

On the other hand, the feature checking approach has been a major feature of the Minimalist Program (see Chomsky 1995 for an initial formulation). Leaving aside the painful instability of its exact implementation, checking of uninterpretable features is assumed to be the trigger of all movements. In the case at hand, the presence of an uninterpretable feature $\mathrm{WH}$ in the head of $\mathrm{CP}$ would probe for an active goal, namely a valued WH feature (41a). Once the goal is found, matching of the $\mathrm{WH}$ feature between the probe and the goal takes place, valuing and deleting the $\mathrm{WH}$ 
feature on the probe (41b). Moreover, if the feature on the probe bears an extra EPP feature, then movement is also required (41c):

(41)
a. $\mathrm{X}_{[\mathrm{WH}]} \ldots$ what $_{[+\mathrm{WH}]}$
b. $\mathrm{X}_{+\ldots \mathrm{H}} \ldots$ what $_{[+\mathrm{WH}]}$
c. what $_{[+\mathrm{WH}]} \mathrm{X}_{[\mathrm{EPP}]} \ldots t$

Even though the machinery is blind to the kind of feature involved, it is crucially designed to get rid of uninterpretable features before the derivation reaches the interfaces -where its presence would cause the derivation to crash. Therefore, in narrow syntax no role is assigned to interpretable features, which raises the theoretical status of those operations that seem to have a purely intepretative motivation, like focus fronting or left and right-dislocation. One obvious solution would be to rephrase the system of criteria developed for the left periphery in terms of interpretative features that need checking, for, even Chomsky has acknowledged that peripheral features might have a role in the computational system after all (Chomsky 2004) -even though he hasn't been any more explicit than several passing-by comments, as usual. Two paradigmatic works within this line are two theses of the 2000: Grohmann (2000), and Villalba (2000).

Yet, including interpretative features in the computational system is not devoid of problems. Particularly, they seriously undermine the autonomy of syntax, since they introduce interpretive needs in the computational system. Furthermore, it should be noted also that a redundancy arises, since the checking of interpretable features is not required by interface conditions and, hence, particular criteria are needed to trigger the operation. Therefore, a strong minimalist proposal should dispense with interpretive-based movement and derive the different interpretative results from the configuration obtained by purely syntactic means (see, for instance, the structures for focus and topic in Rizzi 1997, and the succinct comments in Chomsky 2001). One ambitious work sticking to these standards is López (2003), where all movements to the left periphery are triggered by formal uninterpretable features.

With this in mind, how are exclamative sentences placed in the picture? The answer is in many senses discouraging -particularly if one is prone to adhere to the enthusiastic declarations found in (certain) minimalist literature on the astounding empirical and theoretical success of the Principles and Parameters model. The fact is that the research agenda for exclamatives is full of unsolved questions, in part because, unlike the rich pattern of syntactic effects triggered by $w h$-interrogatives -minimality, superiority, crossover, parasitic gap formation, wh-in-situ-, whexclamatives are far more restricted a phenomenon. ${ }^{7}$ Let us try, however, to determine the syntactic roots of movement in exclamatives.

7. Just to set up the picture, consider two aspects of the syntax of exclamatives that are still awaiting for a proposal -let aside a solution! First, we do not have an explanation for the fact that exclamative wh-words, unlike interrogative ones, are strongly clause-bound: 
Obviously, one possibility is consider that exclamatives must move to the left periphery for feature-checking purposes. Yet, many different versions are found of this idea. A very influential proposal is Bennis et al. (1998), which assumes the following structure for (a type of) Dutch wh-exclamatives (see also Bennis 1998, den Dikken 2006, and Postma 1996):
a. Wat een jongen(s)!
what a young(s)
b. $\left[_{\mathrm{DP}}\right.$ wat $\left._{\mathrm{j}}\left[_{\mathrm{D}}\left[{ }_{\mathrm{D}[+\mathrm{EXCL}]}\left[{ }_{\mathrm{X}} e e n\right]_{\mathrm{i}}\right]\left[_{\mathrm{XP}} \operatorname{jongen}(s)\left[_{\mathrm{X}} t_{\mathrm{i}} t_{\mathrm{j}}\right]\right]\right]\right]$

Crucially, the wh-word is not inherently exclamative, but rather it obtains this interpretation from the fact it lands in the specifier of a determiner with the [+excl] feature, which serves as the force-marker of the structure the DP fits in (an idea that appears recurrently in the literature). However, note that wat 'what' must move for an independent reason, which the authors don't specify.

A more explicit proposal is Castroviejo (2004), where exclamative wh-words are assumed to contain two features: [wh], which encodes their wh nature-shared, hence with $w h$-interrogatives-, and a second one, call it [excl], encoding their specific 'exclamative' content (similar to the E-only morpheme of Zanuttini and Portner 2003). Thus, the exclamative $w h$-word must move to the left periphery to check them (see 4.2 below for a detailed derivation). However, this line of analysis is partly obscured by theory-internal considerations, particularly those concerning the exact nature of the [excl] feature. One important point to be established is the special nature of this feature, which seems to require movement generally. Note in this respect that wh-exclamatives in situ are forbidden in languages with whmovement, and possible under certain conditions in languages without wh-movement, like Japanese (see Ono 2002, 2004):

(43) a. *He loves what a nice woman!

b. *What a nice man loves what a nice woman!

(44) John-wa [nante yuumeina zassi]-ni [nante nagai ronbun]-o J-TOP wh famous journal-DAT wh long paper-ACC oku-tta no da send-PST EXC

'*What a long paper John sent to what a famous publisher!'

(i) a. How very rich you are!

b. ?How very rich I think that you are!

c. ??How very rich John said that I think that you are!

Second, consider the observation by Bosque (1984) that we don't have wh-exclamatives sentences selected by nominals:

(ii) a. La pregunta/*sorpresa de quién vino...

the question/shame of who came 
Moreover, it has been argued that Spanish -and other Romance languages, as well- has a variant of non-wh-exclamative without overt movement (see Masullo 1999):
a. ¡Juan dice cada cosas...! Juan says every things
b. ¡Juan a veces hace unas tonterías...! Juan to times does a.PL sillyness

What these examples teach us is that the impossibility of in-situ wh-exclamatives doesn't stem from a general interpretative ban, but rather from a particular syntactic restriction in a series of particular languages, which is far from being an encouraging conclusion.

A connected fact is the issue of sentence typing and selection, which one may arguably link to the presence of a force feature in the left periphery. The most popular version of such a proposal is Rizzi (1997), where a specialized projection Force Phrase is the responsible for clause-typing. One could assume then that it is here where the [E] feature of Grimshaw (1979) should reside. This is the proposal by Gutiérrez-Rexach (2001), who argues that exclamative wh-words move to the FocusP in the left periphery, and latter to the specifier of ForceP. Schematically:

$$
\left[_{\text {ForceP }} \text { qué }{ }_{j}\left[\text { FocusP }\left[{ }_{A P} \text { tj altos }\right]_{i}\left[\left[_{\text {TopicP }}\left[{ }_{\text {TP }} \text { que son } t_{i}\right]\left[{ }_{\text {FinP }} t_{\text {TP }}\right]\right]\right]\right]\right.
$$

Yet, Zanuttini and Portner (2003) raise arguments against the syntactic encoding of force features. The most compelling one concerns the (insurmountable) difficulties to include all constructions with a given force under the very same set of syntactic properties. Instead, they argue that sentential force is derived from semantic properties that may have different syntactic realizations. In the case at hand, they argue that the exclamative sentential force is the operation of widening (see section 2.1 for a description), which is pragmatically computed from combining a set of alternantives -essentially a wh-word- plus a factive component. ${ }^{8}$ Under such a view, the exclamative type is not encoded in syntax, but deduced from a sum of independent properties. ${ }^{9}$ While burdened with theoretical and empirical problems we have already discussed in section 2.1, one must acknowledge that the widening proposal by Zanuttini and Portner (2003) is the most ambitious and successful attempt at offering the basis for a compositional analysis of exclamative sentences without relying on ad hoc features. For instance, without committing ourselves to the claim

8. As Zanuttini and Portner (2003) carefully remark, the sentential force is the force conventionally associated with a sentence's form. Instead, the illocutionary force of a sentence concerns the speaker intention in uttering such a sentence. So, for instance, a sentence like Could you pass me the salt? has the sentential force of asking, but the illocutionary force of ordering or requesting.

9. Yet, it should be noted that, despite their claims, Zanuttini and Portner (2003) do include information concerning the exclamative meaning in syntax: they make use of the $\mathrm{E}$ (xclamative)-only morpheme to account for the distribution of wh-words in exclamatives. 
that exclamatives contain a FACT(IVE) operator in (one) $\mathrm{CP}$ (projection), we may maintain the advantages of their approach deriving the factive component from the definiteness of the exclamative words, like in the following Spanish constructions (on nominal exclamatives in English, see Portner and Zanuttini 2005; see also Haegeman this volume for important insights concerning modality within the DP):

(47) a. ¡La de gente que vino!

the.FEM of people that came

b. ¡Las tonterías que dijo!

the.FEM sillinesses that said

c. ¡Lo cara que es la casa!

the.NEUT expensive that is the.FEM house

The idea consists in taking advantage of the existential presupposition associated with definite descriptions to explain the apparent factivity of exclamatives without resorting to a null operator. Yet, the details are subtle, and something special should be said concerning hidden exclamatives with indefinite article:

(48)
¡Dice unas
tonterías...!
says a.FEM.PL sillinesses

At this point, a theory of exclamatives connecting them with result clauses (like Castroviejo 2006) may help us to get new insights.

A different approach to the phenomenon is purely semantic: wh-exclamatives must involve movement to the left periphery because the degree operator must have wide scope. This idea is pursued in different -sometimes incompatible- ways by González (this volume), Gutiérrez-Rexach (1999), and Villalba (2003, 2004). All the problems concerning the inclusion of semantically motivated movements in grammar obviously apply, and this leaves without answer the fact that operator scope operations don't seem bound to overt movement crosslinguistically, as Japanese exclamatives and Spanish hidden exclamatives suggest.

\subsection{Moving What}

It is generally assumed that the inventory of exclamative words is a subset of that of interrogative ones, with certain well-known exceptions. Hence, Elliott (1971, 1974) and Grimshaw (1979) established the following list

- ambivalent words: who, what, which, where, when, how

- exclamative: what a

- interrogative: why

This received list has circulated over the years without much variation, but little has been said concerning its underlying rationale. For instance, we still lack an 
answer to the fact that why exclamatives are lacking universally, whereas synonymous versions with for which reason are (more or less) fine. Another complication stems from the fact -noted by Elliott $(1971,1974)$ - that certain wh-words are possible in embedded exclamatives, but impossible in root contexts:

(49) a. It is amazing who came.

b. *Who came!

This restriction is even more cogent in Romance languages, as Catalan (or Spanish) shows:

(50) a. Mira qui va comprar un llibre! look who PAST buy a book

b. No t'imagines on va anar.

not to.you-imagine.you where PAST go

(51) a. *Qui va comprar un llibre!

who PAST buy a book

b. *On va anar!

where PAST go

The interest in pursuing more principled grounds for the inventory of exclamative words has led certain authors to rethink the 'admissibility conditions' of the list. For instance, Castroviejo (2006) revises the properties that one should consider before qualifying a sentence as exclamative. Under her reassessment, the list of ambivalent wh-words becomes null, and -for Catalan-, wh-exclamatives are constructed with que (+ Adj) 'how', quin $(+\mathrm{N})$ 'which', and quants $(+\mathrm{N})$ 'how many':

(52) a. Que alt que és!

how tall that is

b. Quin llibre que va comprar!

which book that PAST buy

c. Quants llibres que va comprar!

how.many.PL books that PAST buy

Castroviejo's reductionist proposal makes perfect sense in a system where the basic ingredient of exclamatives is degree quantification, which builds a close relation between exclamatives and result sentences. Evidence supporting this line of research can be found in the presence of typical result quantifiers like tan 'so' in nominal wh-exclamatives: 
(53)

Quin llibre tan avorrit que va comprar! which book so boring that PAST buy

Indeed, as Castroviejo (2006) argues, degree quantification by tan 'so' is always present in this kind of exclamatives, either explicitly (53) or implicitly (52b). Note that the occurrence of an adjective modifying the noun requires. a tan 'so'-or més 'more' modifier:

(54)

*Quin llibre avorrit que va comprar!

which book boring that PAST buy

A second piece of evidence concerns hidden exclamatives with indefinite article:

(55)

¡Dice unas tonterías...!

says a.FEM.PL sillinesses

Crucially, this kind of exclamatives have been considered instances of elliptical result clauses -note that a declarative intonation would render the sentence ungrammatical: *Dice unas tonterías lit. '(S)he says sillinesses'-, so that the sentence in (55) would derive from

(56) Dice unas tonterías que asustan.

says a.FEM.PL sillinesses that frighten

Even though very tentative, this line of research seems promising in offering an underlying motivation for defining a natural class of exclamative wh-words.

\subsection{Moving Where}

Another sort of difficulties in the study of exclamative sentences concerns the placement of exclamative words in the left periphery. Consider, for instance, the case of Catalan (the most complete description is Castroviejo 2006). Like interrogative ones, exclamative $w h$-words are typically placed in a CP position below dislocated elements:
a. La Maria que alta que és! the Maria that tall.FEM that is 'How tall Maria is!'

b. La Maria què (*que) vol? the Maria what that wants 'What does Maria want?'

Yet, note the presence of the complementizer que 'that' in the exclamative version, which is totally ungrammatical in interrogatives. This is particularly impor- 
tant when subject-predicate inversion is considered, for whereas wh-exclamatives in languages like Catalan, Spanish or Hungarian require obligatory subject-verb inversion (49), they don't in languages like English or French (50):

(58) a. Que intel-ligent que és el Pere! how intelligent that is the Pere

b. ¡Qué intelligente (que) es Pedro! how intelligent that is Pedro

c. (Hogy) mennyire megnôtt Éva! COMP how.much PV-grew-3SG Éva 'How much Éva has grown!' (Lipták 2006)

(59) a. How (very) intelligent John is!

b. Comment Jean est intelligent! how Jean is intelligent 'How intelligent Jean is!'

Since it has been common practice to link subject-verb inversion to wh-movement either through the Wh Criterion or through feature checking, the behavior of exclamative sentences raises several questions. First, is a [wh] feature involved? If so, why is the verb not required to move to $C$ ?

Even though to our knowledge, no specific analysis has been developed to account for this pattern, one way of approaching the issue would be emphasizing the distinct nature of exclamative $w h$-elements, particularly their non-operator status (see Rosselló 2002 for a proposal along these lines, even though for a different reason). We would then link inversion to operator movement. Yet, it is dubious that such a solution might be sustained on the grounds of the evidence furnished by degree $w h$-exclamatives, which crucially supports a operator-degree variable structure. Moreover, such a solution runs into serious trouble when one has a look at languages like Catalan or Spanish, which do show obligatory inversion with $w h$ and even nominal exclamatives: unless one sticks to the unwarranted assumption that $w h$-exclamatives involve an operator-variable in some languages, but not in others, the explanation for this disparate behavior must lay elsewhere.

Note also that the treatment that Catalan and Spanish exclamatives call for raises problems for standard analyses of subject-verb inversion in terms of verb movement to $\mathrm{C}$, for this position seems occupied by the complementizer que 'that'. In other words, if the verb raises over the subject, where is it landing on? This fact apparently gives support for cartographic proposals like Benincà (1996), which argue for a higher CP layer hosting exclamative $w h$-words. Yet, as Castroviejo (2006) argues, one may equally take this as evidence for Barbosa's (2001) analysis of subject-verb inversion. In a nutshell Barbosa analyzes the Spec,TP in Romance null-subject languages as a non-A position capable of hosting wh-elements (an idea that can be traced back to Pesetsky 1987). Consequently, inversion in Romance 
null-subject languages could be reanalyzed in a completely different way than the standard analysis originally developed for English. To rephrase it in recent terms, Romance $\mathrm{T}$ (French aside) can value and delete its noninterpretable phi-features against the VP-internal subject through Agree, without requiring its specifier to be filled. Hence, the Spec, TP remains free for hosting $w h$-elements (and focused material in general). Castroviejo pushes Barbosa's analysis one step further to fit in wh-exclamatives.

She takes exclamative $w h$-words to contain two features: [wh], which encodes their $w h$ nature -shared, hence with $w h$-interrogatives-, and a second one, call it [excl], encoding their specific 'exclamative' content (on the problems derived from the inclusion of interpretable features in the mechanism of feature checking, see 4.1). Crucially, each feature is checked in a different position. First, the exclamative $w h$-word moves to Spec,TP to check the [wh], which blocks subject raising, and forces subject inversion. Then, the $w h$-word moves higher to Spec,CP, to have [excl] checked, ending in a position adjacent to the complementizer que. Schematically:

\section{a. Que intel-ligent que és el Pere! how intelligent that is the Pere}

b. és [el Pere que intel-ligent] ?

c. $\left[_{\mathrm{TP}}\right.$ que intel-ligent ${ }_{\mathrm{k}}\left[_{\mathrm{T}}\right.$, és ${ }_{\mathrm{i}}\left[{ }_{\mathrm{VP}} t_{\mathrm{i}}\left[\right.\right.$ el Pere $\left.\left.\left.\left.t_{\mathrm{k}}\right]\right]\right]\right] \rightarrow$

d. $\left[{ }_{\mathrm{CP}}\right.$ que intel-ligent ${ }_{\mathrm{k}}\left[{ }_{\mathrm{C}}\right.$, que [TP $t_{\mathrm{k}}{ }_{\mathrm{T}}$, és ${ }_{\mathrm{i}}\left[{ }_{\mathrm{VP}} t_{\mathrm{i}}\left[\right.\right.$ el Pere $\left.\left.\left.\left.\left.\left.t_{\mathrm{k}}\right]\right]\right]\right]\right]\right]$

Hence, Castroviejo's extension of the analysis of inversion by Barbosa (2001) permits a straightforward account of the main properties of $w$-exclamatives without resorting to CP-recursion, nor prolific peripheries. ${ }^{10}$

\subsection{Movement interferences}

One important -yet underinvestigated- aspect of the syntax of exclamative sentences concerns the displacement of the exclamative $w h$-word out of islands. Even though $w h$-exclamatives are usually clause-bound for unknown reasons, the intervention effects of negation have raised some attention (see González this volume, and Villalba 2004; see also section 2.3 above). Interestingly, taking advice from the fact that the early syntactic formulation of the phenomenon (Rizzi 1990, Ross 1984) was subject to strong critique by Kuno and Takami (1997), who advocated for an intepretative solution, González (this volume) (see Villalba 2004 for a similar

10. Notwithstanding, it is still a mystery why Catalan exclamatives must -and Spanish exclamatives tend to- fill the $\mathrm{C}$ position with the complementizer que. Interestingly, this is quite recent a construction in Catalan, for it is totally absent from Catalan texts, at least until the XVII century. One promising line of research might involve the analogical extension of que from subordinate non-wh-exclamatives headed by a definite determiner (Les coses que diu! 'The things (s)he says!') to wh- ones. Yet, a more detailed study is certainly deserved. 
intuition, even though couched in different terms) pursue a semantic approach, crucially relying on the scope interaction between the exclamative and the negative operators.

\section{Conclusions}

We have reviewed the basic semantic components of exclamatives, namely high/extreme degree (2.1), the expressive content (2.2), and factivity (2.3), while showing that none of them raise a wide consensus, nor an unproblematic analysis - the same situation holds for the semantic type of exclamatives (2.4). Empirical and theoretical evidence has been presented from the literature against a characterization of exclamatives in terms of extreme degree and factivity, while the formalization of their expressive semantic component has proven a more fruitful approach, which will unquestionably become prominent in the research agenda.

As for the pragmatic aspect, it has been shown that, even though they could be claimed to be paradigmatic instances of the expressive speech act, there are very few attempts to include exclamatives in the framework developed by Searle (1969, 1979). Something similar applies to the placement of exclamatives in a model of discourse along the lines developed by Robert C. Stalnaker, so that it is still to be determined in detail how they contribute to the Common Ground, and the mechanisms involved. Again, one can expect these questions to become a lively area of research in a recent future.

Finally, as for the syntactic form of exclamatives, without doing justice to the wide pattern of crosslinguistic variation, we haven't found a unified analysis of the exclamative sentence type. Concerning the motivation of movement, both the criterion-based and the feature-based approach have proved problematic on empirical and theoretical grounds, particularly the justification of an [exclamative] feature as the movement trigger. When attention was paid to the element moved, we showed that the received view was under strong revision that exclamative $w h$-words are derived from a bigger list of interrogative $w h$-words, for it provided no grounds for defining a natural class for the former. Finally, concerning the placement of exclamative $w h$-words. the conclusion was that, at least for languages like Catalan, it was unnecessary to resort to prolific peripheries as invoked in the cartographic approach to syntax.

On the whole, the picture following from this succinct survey is that exclamative sentences represent a much unexplored field, which is expected to become a growing, and exciting research area in the following years; for many of the empirical and theoretical problems here reviewed dwell at the very core of the syntax/semantics, and semantics/pragmatics interfaces.

\section{References}

Abels, Klaus (2004). "Why Surprise-Predicates do not Embed Polar Interrogatives". Linguistische Arbeitsberichte 79.

Asher, Nicholas; Lascarides, Alex (1998). "Questions in Dialogue". Linguistics and Philosophy 21: 237-309. 
Atlas, Jay D. (2005). Logic, Meaning, and Conversation: Semantical Underdeterminacy, Implicature, and Their Interface. Oxford: Oxford University Press.

Austin, John L. (1962). How to Do Things with Words. Cambridge, Mass.: Harvard University Press.

Bennett, Michael R. (1977). “A Response to Karttunen on Questions”. Linguistics and Philosophy 1: 279-300.

Bennis, Hans (1998). “Exclamatives!”. In: van Bezooijen, René; Kager, René (eds.). Linguistics in the Netherlands 1998. Amsterdam/Philadelphia: John Benjamins, pp. 27-40.

Bennis, Hans; Corver, Norbert; den Dikken, Marcel (1998). "Predication in Nominal Phrases". Journal of Comparative Germanic Linguistics 1: 85-117.

Bittner, Maria (1998). "Cross-Linguistic Semantics for Questions”. Linguistics and Philosophy 21: 1-82.

Bosque, Ignacio (1984). "Sobre la sintaxis de las oraciones exclamativas", Hispanic Linguistics 1: 283-304.

Brody, Michael (1990). "Remarks on the Order of Elements in the Hungarian Focus Field". In Approaches to Hungarian. Volume 3. Szeged: JATE.

Castroviejo, Elena (2006). Wh-Exclamatives in Catalan. Universitat de Barcelona, doctoral dissertation.

Castroviejo, Elena (this volume). "Deconstructing Exclamations". Catalan Journal of Linguistics 7: 41-90.

Cheng, Lisa; Corver, Norbert (Eds.). (2006). Wh-Movement. Moving on. Cambridge, Mass.: MIT Press.

Chomsky, Noam (1975[1955]). The Logical Structure of Linguistic Theory. New York: Plenum.

Chomsky, Noam (1957). Syntactic Structures. The Hague: Mouton.

Chomsky, Noam (1965). Aspects of the Theory of Syntax. Cambridge, Mass.: MIT Press.

Chomsky, Noam (1973). "Conditions on Transformations". In: Essays on Form and Interpretation. Amsterdam: North-Holland. pp. 81-162.

Chomsky, Noam (1975). "Questions of Form and Interpretation”. Linguistic Analysis 1: 75-109.

Chomsky, Noam (1981). Lectures on Government and Binding. Dordrecht: Foris.

Chomsky, Noam (1995). The Minimalist Program. Cambridge, Mass.: MIT Press. Chomsky, Noam (2001). "Derivation by Phase". In: Michael Kenstowicz (ed.). Ken Hale: A Life in Language. Cambridge, Mass.: MIT Press.

Chomsky, Noam (2004). "Beyond Explanatory Adequacy”. In: Belletti, Adriana (ed.). Structures and Beyond. The Cartography of Syntactic Structures, volume 3. New York: Oxford University Press. pp. 104-131.

D'Avis, Franz-Josef (2002). "On the Interpretation of Wh-Clauses in Exclamative Environments". Theoretical Linguistics 28: 5-31.

den Dikken, Marcel (2006). Relators and Linkers. Cambridge, Mass.: MIT Press.

Elliott, Dale (1971). "The Grammar of Emotive and Exclamatory Sentences in English". Ohio State Working Papers in Linguistics 8: viii-110.

Elliott, Dale (1974). "Toward a Grammar of Exclamations". Foundations of Language 10: 41-53. 
Espinal, M. Teresa (1997). "Non-Negative Negation and Wh-Exclamatives”. In: Forget, Daniel; Hirschbühler, Paul; Martineau, France; Rivero, M. Luisa (eds.). Negation and Polarity. Syntax and Semantics. Amsterdam/Philadelphia: John Benjamins. pp. 75-93.

Gauker, Christopher (2003). Words without Meaning. Cambridge, Mass.: MIT Press.

Gérard-Naef, Jocelyn (1980). L'exclamation en français: la syntaxe des phrases et des expressions exclamatives. Tübingen: Max Niemeyer.

Ginzburg, Jonathan (1995a). "Resolving Questions I". Linguistics and Philosophy 18: 459-527.

Ginzburg, Jonathan (1995b). "Resolving Questions II". Linguistics and Philosophy 18: 567-609.

Ginzburg, Jonathan; Sag, Ivan (2001). Interrogative Investigations: The Form, Meaning, and Use of English Interrogatives. Stanford: CSLI Publications.

González, Raquel (this volume). "Exclamative Wh-Phrases as Positive Polarity Items". Catalan Journal of Linguistics 7: 91-116.

Grice, Paul (1989). Studies in the Way of Words. Cambridge, Mass.: Harvard University Press.

Grimshaw, Jane (1979). “Complement Selection and the Lexicon”. Linguistic Inquiry 10: $279-326$.

Groenendijk, Jeroen; Stokhof, Martin (1982). "Semantic Analysis of Wh-Complements". Linguistics and Philosophy 5: 175-234.

Groenendijk, Jeroen; Stokhof, Martin (1989). "Type-Shifting Rules and the Semantics of Interrogatives". In: Chierchia, Gennaro; Turner, Raymond (eds.). Properties, Types and Meanings, vol. 2, Semantic Issues. Dordrecht: Kluwer. pp. 21-68.

Grohmann, Kleanthes (2000). Prolific Peripheries: A Radical View from the Left. University of Maryland, doctoral dissertation.

Gunlogson, Christine (2001). True to Form: Rising and Falling Declaratives as Questions in English. University of California, Santa Cruz, doctoral dissertation.

Gutiérrez-Rexach, Javier (1996). "The Semantics of Exclamatives". In: Garrett, E.; Lee, F. (eds.). Syntax at Sunset. UCLA Working Papers in Linguistics. Los Angeles: UCLA. pp. 146-162.

Gutiérrez-Rexach, Javier (1999). "The Structure and Interpretation of Spanish Degree Neuter Constructions”. Lingua 109: 35-63.

Gutiérrez-Rexach, Javier (2001). "Spanish Exclamatives and the Interpretation of the Left Periphery”. In: Rooryck, Johan; de Hulst, Yves; Schroten, Jan (eds.). Selected Papers from Going Romance 99. Amsterdam/Philadelphia: John Benjamins.

Gutiérrez-Rexach, Javier (this volume). "Spanish Root Exclamatives at the Syntax/Semantics Interface". Catalan Journal of Linguistics 7: 117-133.

Haegeman, Liliane; Zanuttini, Raffaella (1996). "Negative Concord in West Flemish". In: Belletti, Adriana; Rizzi, Luigi (eds.). Parameters and Functional Heads. New York: Oxford University Press. pp. 117-179.

Haegeman, Liliane (this volume). "Pleonastic tet in the Lapscheure dialect". Catalan Journal of Linguistics 7: 157-199.

Hamblin, C. L. (1973). Questions in Montague English. Foundations of Language 10: 41-53.

Higginbotham, James (1991). "Interrogatives”. In: Hale, Ken; Keyser, Samuel J. (eds.). The View from Building 20. Cambridge, Mass.: MIT Press. 
Huang, James (1982). Logical Relations in Chinese and the Theory of Grammar. MIT, doctoral dissertation.

Karttunen, Lauri (1977). "Syntax and Semantics of Questions". Linguistics and Philosophy 1: 3-44.

Katz, Jerry; Postal, Paul (1964). An Integrated Theory of Linguistic Descriptions. Cambridge, Mass.: MIT Press.

Kuno, Susumo; Takami, K. (1997). "Remarks on Negative Islands". Linguistic Inquiry 28: 553-576.

Lasnik, Howard; Saito, Mamoru (1992). Move Alpha. Cambridge, Mass.: MIT Press. Lewis, David (1970). "General Semantics". Synthese 22: 18-67.

Lipták, Anikó (2006). "Word Order in Hungarian Exclamatives". Acta Linguistica Hungarica 53: 343-391.

López, Luis (2003). "Steps for a Well-Adjusted Dislocation”. Studia Linguistica 57: 193-231.

Martinich, Aloysius P. (2001). "John R. Searle”. In: Martinich, Aloysius P.; Sosa, David (eds.). A Companion to Analytic Philosophy. Oxford: Blackwell. pp. 434-450.

Masullo, Pascual (1999). “On Hidden Exclamatives in Spanish”. Universidad Nacional del Comahue, unpublished manuscript.

Mayol, Laia (this volume). "Catalan "Déu n'hi do" and Conventional Implicatures in Exclamatives”. Catalan Journal of Linguistics 7: 135-156.

Milner, Jean-Claude (1978). De la syntaxe à l'interprétation. Paris: Seuil.

Ono, Hajime (2002). "Exclamatory Sentences in Japanese: A Preliminary Study". In: Otsu, Yukio (ed.). The Proceedings of the Third Tokyo Conference on Psycholinguistics. Tokyo: Hituzi Syobo Publications, pp. 305-326.

Ono, Hajime (2004). “On Multiple Exclamatives”. University of Maryland, unpublished manuscript.

Partee, Barbara (2004). "Reflections of a Formal Semanticist". In: Compositionality in Formal Semantics. Selected Papers by Barbara Partee. Oxford: Blackwell. pp. 1-25.

Pesetsky, David (2000). Phrasal Movement and Its Kin. Cambridge, Mass.: MIT Press.

Portner, Paul; Partee, Barbara (eds.). (2002). Formal Semantics. The Essential Readings. Oxford: Blackwell.

Portner, Paul, and Zanuttini, Raffaella (2000). "The Force of Negation in WHExclamatives and Interrogatives". In: Horn, Laurence; Kato, Y. (eds.). Negation and Polarity. Syntactic and Semantic Perspectives. New York: Oxford University Press. pp. 1-25.

Portner, Paul; Zanuttini, Raffaella (2005). "The Semantics of Nominal Exclamatives". In: Stainton, R.; Elugardo, R. (eds.). Ellipsis and Non-Sentential Speech. Dordrecht: Kluwer, pp. 57-67.

Postma, Gert (1995). "Exclamative Wh and Verb-Second". In: Cremers, Crit; den Dikken, Marcel (eds.). Linguistics in the Netherlands 1996. Amsterdam/Philadelphia: John Benjamins, pp. 207-220.

Potts, Chris (2005). The Logic of Conventional Implicatures. New York: Oxford University Press.

Potts, Chris (2007). “The Expressive Dimension”. Theoretical Linguistics 33: 165-198.

Richards, Norvin (1997). What Moves Where in Which Language. MIT, doctoral dissertation. 
Rizzi, Luigi (1982). Issues in Italian Syntax. Dordrecht: Foris.

Rizzi, Luigi (1990). Relativized Minimality. Cambridge, Mass.: The MIT Press.

Rizzi, Luigi (1996). "Residual Verb Second and the WH-Criterion". In: Belletti, Adriana; Rizzi, Luigi (eds.). Parameters and Functional Heads. New York: Oxford University Press.

Ross, John R. (1967). Constraints on Variables in Syntax. MIT, doctoral dissertation. Ross, John R. (1971). “On Declarative Sentences”. In: Jacobs, R.; Rosenbaum, P. (eds.). Readings in English Transformational Grammar. Waltham: Ginn.

Ross, John R. (1984). "Inner Islands". Proceedings of Berkeley Linguistics Society 10: 258-265.

Rudin, Catherine (1988). "On Multiple Questions and Multiple WH Fronting”. Natural Language \& Linguistic Theory 6: 445-502.

Rullmann, Hotze (1995). Maximality and the Semantics of Wh-Constructions. University of Massachusetts, Amherst, doctoral dissertation.

Sadock, Jerry (1970). "Wh-Imperatives”. In: Sadock, Jerry; Vanek, A. (eds.). Studies Presented to R. B. Lees by His Students. Edmonton: Linguistic Research Inc.

Saebø, Kjell-Johan (2005). "Explaining Clausal Exclamatives". Paper presented at the JSM05, Paris.

Schlenker, Paul (2007). "Expressive Presuppositions". Theoretical Linguistics 33: 237-245

Searle, John R. (1969). Speech Acts: An Essay in the Philosophy of Language. Cambridge: Cambridge University Press.

Searle, John R. (1979). Expression and Meaning: Studies in the Theory of Speech Acts. Cambridge: Cambridge University Press.

Searle, John R. (2001). "J. L. Austin”. In: Martinich, Aloysius P.; Sosa, David (eds.). A Companion to Analytic Philosophy. Oxford: Blackwell. pp. 218-230.

Stalnaker, Robert C. (1978). "Assertion". In: Cole, Peter (ed.), Pragmatics. Syntax and Semantics, vol. 9. New York: Academic Press. pp. 315-332. [Reprinted in Stalnaker 1999]

Stalnaker, Robert C. (1988). "Belief Attribution and Context". In: Grimm, R.; Merrill, D. (eds.). Contents of Thought. Tucson: University of Arizona Press. pp. 140-156. [Reprinted in Stalnaker 1999]

Stalnaker, Robert C. (1998). "On the Representation of Context". Journal of Logic, Language, and Information 7: 3-19. [Reprinted in Stalnaker 1999]

Stalnaker, Robert C. (1999). Context and Content. Oxford/New York: Oxford University Press.

Villalba, Xavier (2003). "An Exceptional Exclamative Sentence Type in Romance". Lingua, 113: 713-745.

Villalba, Xavier (2004). "Exclamatives and Negation" (Technical Research Report GGT-2004-02). Bellaterra: Grup de Gramàtica Teòrica, Universitat Autònoma de Barcelona.

Zanuttini, Raffaella; Portner, Paul (2003). "Exclamative Clauses: At the Syntax-Semantics Interface". Language 79: 39-81.

Zimmerman, Thomas Ede (1985). "Remarks on Groenendijk and Stokhof's Theory of Indirect Questions". Linguistics and Philosophy 8: 431-448. 